\title{
Analisis Tingkat Stres Akademik Pada Mahasiswa Selama Pembelajaran Jarak Jauh Dimasa Covid-19
}

\author{
Ade Chita Putri Harahap ${ }^{1 *}$, Dinda Permatasari Harahap ${ }^{2}$, Samsul Rivai Harahap ${ }^{3}$. \\ ${ }^{1}$ Universitas Islam Negeri Sumatera Utara, Indonesia. \\ 2Universitas Medan Area, Indonesia. \\ 3SMA Negeri 1 Sidamanik \\ *Korespondensi: adechitaharahap@uinsu.ac.id
}

\begin{abstract}
The variety of stressors in lectures online for a pandemic COVID-19 as an internet connection is not tasty, complete the task that much in a short time, to respond to instructions quickly, as well as the need to adapt rapidly to the situation of learning from home is a condition that can cause stress on students. Ideally, the learning process carried out remotely can enhance the learning process. This change will certainly not be easy for students, including students. This study aims to determine the level of academic stress on students. This research uses a descriptive quantitative approach. The sample of this research is 300 students. Data were analyzed using descriptive formulas. Data collection is done using a Likert type scale that has been tested for validity and reliability. Based on data analysis, the results show that, on average, students experience stress in the medium category.
\end{abstract}

Keywords: Academic Stress; College Students; COVID-19.

\begin{abstract}
Abstrak
Bervariasinya stresor dalam perkuliahan daring selama pandemic covid-19 seperti koneksi internet yang kurang baik, menyelesaikan tugas yang banyak dalam waktu yang cepat, merespon instruksi dengan cepat, serta perlu beradaptasi cepat dengan situasi belajar dari rumah merupakan kondisi yang dapat menimbulkan stres pada mahasiswa. Idealnya, Proses pembelajaran dilakukan secara jarak jauh dapat mempermuda proses pembelajaran. Perubahan ini tentu menjadi hal yang tidak mudah bagi para pelajar termasuk mahasiswa. Penelitian ini bertujuan untuk mengetahui tingkatan stres akademik pada mahasisw. Penelitian ini menggunakan pendekatan kuantitatif deskriptif. Sampel berjumlah 300 mahasiswa. Data dianalisis menggunakan rumus deskriptif. Pengumpulan data dilakukan menggunakan Skala berjenis Likert yang telah diuji validitas dan reliabilitasnya. Berdasarkan analisis data, diperoleh hasil bahwa secara rata-rata mahasiswa mengalami stres dalam kategori sedang.
\end{abstract}

Kata Kunci: Stres Akademik; Mahasiswa; COVID-19.

How To Cite : Harahap, A. C. P., Harahap, D. P., \& Harahap, S. R., (2020). Analisis Tingkat Stres Akademik Pada Mahasiswa Selama Pembelajaran Jarak Jauh Dimasa Covid-19. Biblio Couns: Jurnal Kajian Konseling dan Pendidikan, 3(1), 10-14.

\begin{tabular}{l} 
(C) (?) $\begin{array}{l}\text { This is an open access article distributed under the Creative Commons } 4.0 \text { Attribution License, which } \\
\text { permits unrestricted use, distribution, and reproduction in any medium, provided the original work is } \\
\text { properly cited.(O2020 by author }\end{array}$ \\
\hline SA
\end{tabular}

\section{PENDAHULUAN}

Pandemi COVID-19 yang pertama kali muncul di Wuhan, China pada akhir tahun 2019 membuat masyarakat dunia khawatir. Diketahui bahwa penyebaran COVID-19 ke negara lain sangat cepat dan semakin meluas. Banyak masyarakat dunia yang terpapar dan terinfeksi 
COVID-19. Hal ini membuat pemerintahan dari berbagai negara melakukan lock down. Lock down adalah kondisi dimana seluruh aktifitas yang ada dihentikan untuk sementara agar penyebaran virus corona dapat diminimalisir. Sehingga pada akhirnya setiap negara memberlakukan stay at home (tetap berada di rumah) bagi seluruh masyarakat.

Ditetapkannya COVID-19 sebagai pandemi global membuat pemerintah Indonesia membuat beberapa kebijakan strategis agar menghindari penularan virus ini. Pemerintah mengambil kebijakan dan menghimbau masyarakat untuk melakukan physical distancing. Hal ini juga diperkuat dengan data jumlah Orang Dengan Pantauan dan Pasien Dalam Pantauan yang jumlahnya semakin meningkat setiap hari. Hingga bulan April 2020, jumlah PDP sebanyak 10.482 dan ODP sebanyak 139.137. Pada 13 April 2020, Presiden Indonesia mengeluarkan Keputusan Presiden (Keppres) Nomor 12 Tahun 2020 tentang Penetapan Bencana Non Alam Penyebaran Corona Virus Disease 2019 (COVID-19) sebagai Bencana Nasional.

Negara Indonesia juga melakukan lock down dengan memberlakukan PSBB (pembatasan sosial berskala besar). Pemerintah melalui surat edarannya juga memerintahkan seluruh aktifitas pembelajaran dilakukan di rumah (sekolah dari rumah/daring) dan bekerja dari rumah (WFH). Institusi pendidikan mulai dari tingkat prasekolah hingga perguruan tinggi ditutup untuk sementara waktu. Aktivitas pembelajaran dilakukan secara jarak jauh. Mahasiswa di perguruan tinggi juga merasakan dampak dan akibat dari COVID19. Kegiatan perkuliahan dilakukan secara jarak jauh melalui aplikasi-aplikasi yang mendukung kegiatan perkuliahan. Berbagai platform dapat digunakan oleh mahasiswa untuk membantunya dalam mengerjakan tugas, menjalani proses perkuliahan, melaporkan aktifitas perkuliahan secara daring. Namun tidak dipungkiri bahwa adanya hambatan-hambatan yang terjadi selama proses perkuliahan dilakukan secara daring.

Kendala-kendala yang dihadapi oleh mahasiswa seperti jaringan yang tidak ada, paket internet yang habis, pekerjaan rumah yang harus dikerjakan juga, dan tugas perkuliahan yang menumpuk. Berbagai tuntutan akademik yang harus diselesaikan oleh mahasiswa menyebabkan mereka mengalami stres akademik. Ketidakmampuan mahasiswa untuk beradaptasi dengan keadaan tersebut membuat mereka mengalami stres. Stres akademik diartikan sebagai keadaan dimana seseorang tidak dapat menghadapi tuntutan akademik dan mempersepsi tuntutan akademik yang diterima sebagai gangguan (Barseli, dkk, 2017). Alvin (dalam Eryanti, 2012) menjelaskan bahwa stres akademik merupakan tekanan yang terjadi pada diri mahasiswa yang disebabkan oleh adanya persaingan ataupun tuntutan akademik.

Stres akademik disebabkan oleh adanya academic stressor (Sayekti dalam Barseli, 2017). Academic stressor merupakan yaitu penyebab stres yang bermula dari proses pembelajaran seperti tekanan untuk mendapatkan nilai yang baik, lamanya belajar, banyaknya tugas, rendahnya nilai/prestasi dan cemas dalam menghadapi ujian (Rahmawati dalam Barseli, dkk, 2017). Barseli, dkk., (2017) menjelaskan bahwa stres akademik merupakan tekanan yang diakibatkan adanya perspektif subjektif terhadap suatu kondisi akademik. Oon (2007) menjelaskan bahwa stres akademik yang dialami oleh mahasiswa yang secara terus menerus menimbulkan penurunan daya tahan tubuh mahasiswa sehingga mudah mengalami penurunan daya tahan tubuh. Hasil penelitian Siregar dan Putri (2019) menjelaskan bahwa stress akademik dipengaruhi oleh Self-Efficacy dengan korelasi negative. Hasil penelitian Liu (2011) mendapatkan hasil bahwa 90\% subjek penelitian mengajlami stres akademik yang disebabkan oleh ujian, kurangnya prestasi, penundaan tugas, pekerjaan rumah, iklim sekolah yang kurang mendukung, serta keyakinan dan kemauan belajar. Sagita (2017) menjelaskan bahwa mahasiswa yang mengalami stres akademik cenderung dipengaruhi oleh keterampilan dalam manajemen waktu antara belajar dan kegiatan lainnya. 
Hasil penelitian terakhir dari Sagita (2017) menggambarkan bahwa stres akademik mahasiswa BK FIP UNP tergolong masih pada kategori rendah. Berdasarkan berbagai literatur mengenai penyebab stres akdemik pada mahasiswa, penelitian ini juga ingin melihat gambaran stres akademik selama masa pembelajaran jarak jauh di tengah-tengah pandemik COVID-19. Hal ini dikarenakan mahasiswa perlu melakukan penyesuaian dengan kondisi baru di tengah-tengah pandemik.

\section{METODE}

Jenis penelitian ini adalah pendekatan kuantitatif dengan menggunakan metode deskriptif. Menurut Lehman (dalam Yusuf, 2014) penelitian deskriptif kuantitatif adalah salah satu jenis penelitian yang bertujuan untuk mendesripsikan secara sistematis, faktual dan akurat mengenai fakta dan sifat tertentu, atau mencoba menggambarkan fenomena secara detail.

Adapun subjek penelitian ini adalah mahasiswa BKI Fakultas IImu Tarbiyah dan Keguruan UINSU Medan sebanyak 300 orang yang pengambilan sampelnya menggunakan random sampling. Pada penelitian ini alat yang digunakan adalah kuesioner skala stres akademik yang penulis susun untuk digunakan sebagai alat ukur. Alat ukur stres akademik ini menggunakan skala Likert. Penelitian ini menggunakan format deskriptif survei yang memungkinkan peneliti untuk melakukan generalisasi suatu variabel tertentu pada populasi yang besar (Bungin, 2005). Gambaran stres akademik tersebut akan menjelaskan secara menyeluruh aspek-aspek dari stres akademik dalam bentuk presentase. Skala stres akademik terdiri dari 22 item pernyataan mengenai kondisi stres akademik yang dialami mahasiswa selama perkuliahan jarak jauh.

\section{HASIL DAN PEMBAHASAN}

Data dianalisis menggunakan bantuan software SPSS. Berdasarkan hasil analisis yang dilakukan terhadap stres akademik mahasiswa UINSU diperoleh hasil sebagai berikut:

Tabel 1. Statistik Deskriptif Variabel Stres Akademik

\begin{tabular}{cccccc}
\hline Variabel & N & Minimal & Maksimal & Mean & Deviasi Standar \\
\hline Stres akademik & 300 & 22 & 20 & 74.83 & 14.831 \\
\hline
\end{tabular}

Berdasarkan tabel di atas, dapat diketahui bahwa nilai rata-rata variabel stres akademik diperoleh nilai sebesar 74,83 dan memiliki deviasi standar sebesar 14,831. Peneliti melakukan kategorisasi terhadap skor total yang diperoleh responden dengan menggunakan rumus berikut:

Tabel 2. Menentukan Kategorisasi Tingkat Stres Akademik

\begin{tabular}{lll}
\hline \multicolumn{1}{c}{ Kategori } & \multicolumn{1}{c}{ Rumus } & \multicolumn{1}{c}{ Hasil Kategorisasi } \\
\hline Rendah & $X<M-1 S D$ & $X<60$ \\
Sedang & $M-1 S D \leq M=1 S D$ & $60 \leq X \leq 90$ \\
Tinggi & $M+1 S D$ & $X>90$ \\
\hline
\end{tabular}

Berdasarkan rumus tersebut, data kemudian dikelompokkan menjadi tiga kategori yakni tingkat stres rendah, sedang, dan tinggi yang frekuensinya dapat dilihat pada tabel berikut: 
Biblio Couns : Jurnal Kajian Konseling dan Pendidikan | Vol. 3 No. 1 Maret 2020

Tabel 3. Frekuensi dan Persentase Stres Akademik

\begin{tabular}{lcc}
\hline \multicolumn{1}{c}{ Kategori } & Frekuensi & Persentase \\
\hline Tinggi & 39 & 13 \\
Sedang & 225 & 75 \\
Rendah & 36 & 12 \\
Total & 300 & 100 \\
\hline
\end{tabular}

Berdasarkan tabel di atas, dapat diketahui bahwa dari 300 orang mahasiswa yang dijadikan sampel penelitian, terdapat sebanyak 39 mahasiswa (13\%) yang memiliki tingkat stres akademik kategori tinggi, sebanyak 225 mahasiswa (75\%) memiliki tingkat stres akademik pada kategori sedang, dan sebanyak 36 mahasiswa (12\%) memiliki tingkat stres akademik yang berada pada kategori rendah. Tingkat presentasi stres akademik yang dialami mahasiswa dapat dilihat pada gambar berikut:

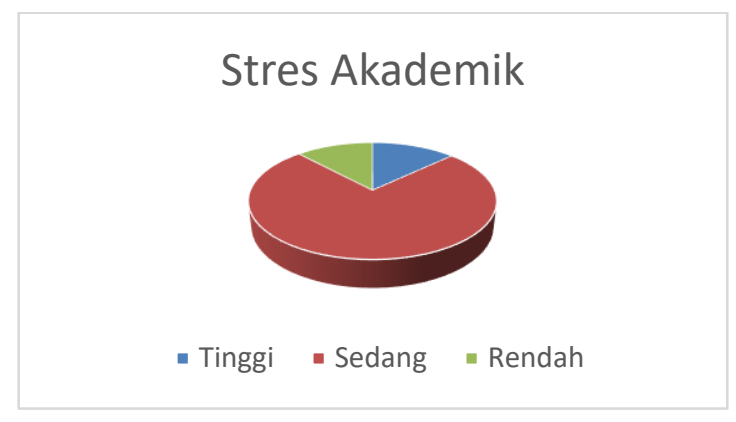

\section{Gambar 1. Persentase Tingkat Stres Akademik}

Berdasarkan tabel dan gambar di atas, dapat disimpulkan bahwa Hal ini bahwa mayoritas mahasiswa mengalami stress akademik selama belajar jarak jauh di tengah-tengah kondisi pandemi COVID-19.

\section{REFERENSI}

Barseli, dkk. (2017). Konsep Stres Akademik Siswa. Jurnal Konseling dan Pendidikan, 5 (03): 143-148.

Bungin, B. (2005). Metode Penelitian Kuantitatif: Komunikasi, Ekonomi, dan Kebijakan Publik serta Ilmu-ilmu Sosial Lainnya. Jakarta: Kencana.

Eryanti, F. (2012). Perbedaan Stres Akademik antara kelompok Siswa Minoritas dengan Mayoritas di SMP WR Supratman 2 medan. Jurnal USU, 7 (06): 145-162.

Liu, Y., \& Lu, Z. (2011). The Chinese high school student's stress in the school and academic achievement. Educational Psychology: An International Journal of Experimental Educational Psychology, 31(1), 27-35.

Yusuf, A. M. (2014). Metode Penelitian: Kuantitatif, kualitatif, dan penelitian gabungan. Jakarta: Kencana Prenada Media Group.

Oon, A.N. (2007). Handling Study Stress. Jakarta: Alex Media Komputindo. 
Biblio Couns : Jurnal Kajian Konseling dan Pendidikan | Vol. 3 No. 1 Maret 2020

Sagita, dkk. (2017). Hubungan Self Efficacy, Motivasi Berprestasi, Prokrastinasi Akademik dan Stres Akademik Mahasiswa. Jurnal Bikotetik, 1 (02): 37-72.

Siregar, I. K., \& Putri, S. R. (2020). Hubungan Self-Efficacy dan Stres Akademik Mahasiswa. Consilium: Berkala Kajian Konseling dan IImu Keagamaan, 6(2), 91-95. 